\title{
Downregulation of Tumor Necrosis Factor Expression in the Human Mono-Mac-6 Cell Line by Lipopolysaccharide
}

\author{
Jürgen G. Haas, Corinna Thiel, Kathi Blömer, Elisabeth H. Weiss, Gert Riethmüller, and \\ H.W. Löms Ziegler-Heitbrock \\ Institute for Immunology, University of Munich, Munich, Federal Republic of Germany

\begin{abstract}
Mono-Mac-6 cells, but not U937 cells, can be induced to rapidly express tumor necrosis factor (TNF) mRNA and protein when triggered with lipopolysaccharide (LPS) at $1 \mu \mathrm{g} / \mathrm{ml}$. Preincubation of the cells for $3 \mathrm{~d}$ with low amounts of LPS $(10 \mathrm{ng} / \mathrm{ml})$ results in nearly complete suppression of TNF secretion. This downregulation appears to occur at the tions. By contrast, the same preincubation with $10 \mathrm{ng} / \mathrm{ml}$ LPS results in enhanced phagocytosis (28.6-67.2\% for Staphylococcus aureus), demonstrating that not all monocyte functions are suppressed. While these results show that only stringent exclusion of LPS from culture media allows for induction of TNF in the Mono-Mac-6 cell line, the pronounced effect of LPS preincubation may also provide a sultable model with which to study the mechaniems of LPS-induced desensitization.
\end{abstract} \\ pretranslational level since specific mRNA is virtually undetectable under these condi- \\ Key words: TNF, LPS, Desensitization
}

\section{INTRODUCTION}

We have recently established the Mono-Mac-6 human monocytic cell line, which has many of the phenotypic and functional characteristics of peripheral blood monocytes [17]. When studying expression of tumor necrosis factor (TNF) in this cell line we noted that this cytokine could not be induced in every experiment. Only after stringent exclusion of LPS from the culture media reproducible stimulation of TNF was observed. Hence, we initiated experiments to investigate the impact of low amounts of LPS in a preculture period on subsequent TNF response to high amounts of LPS. As we will demonstrate in the present study, LPS can in fact downregulate TNF expression and this appears to occur at the mRNA level.

\section{MATERIALS AND METHODS}

\section{Cell Culture}

The cell lines Mono-Mac-6 [17] and U937 [12] (kindly provided by $\mathrm{K}$. Nilsson) were maintained in LPS-free $(<10 \mathrm{pg} / \mathrm{ml}$ as determined by Limulus amebocyte lysate (LAL) assay) RPMI 1640 culture medium (Gibco, Grand Island, NY) supplemented with 10\% FCS (Interchem, Munich, F.R.G.), penicillin-streptomycin (Gibco), nonessential amino acids (Gibco), insulin (Sigma, St. Louis, MO), oxalacetate (Sigma), pyruvate (Fluka, Buchs, Switzerland) and L-glutamine (Gibco).
To ensure freedom of LPS the complete culture medium was ultrafiltrated [2] through a Gambro 2000 column (Gambro, Hechingen, F.R.G.) followed by addition of FCS. In this medium, cells were cultured for $3 \mathrm{~d}$ either with or without $10 \mathrm{ng} / \mathrm{ml}$ LPS from Salmonella minnesota (\# L 6261, Sigma) at a cell density of $2 \times 10^{5}$ cells/ $\mathrm{ml}$. After this preculture cells were stimulated with 1 $\mu \mathrm{g} / \mathrm{ml} \mathrm{LPS} \mathrm{for} \mathrm{3-6} \mathrm{h} \mathrm{at} 2 \times 10^{6}$ cells/ml in 24-well plates. Supernatants were transferred into centrifugation tubes, spun twice at $800 \mathrm{~g}$ in order to eliminate cells, and the supernatant was tested for TNF bioactivity.

\section{TNF Bioassay}

TNF in the supernatants was determined in a ${ }^{51} \mathrm{Cr}$-release assay with actinomycin D-pretreated WEHI 164 as target cells exactly as described earlier $[15,16]$. Specific release from WEHI 164 cells as a measure of TNF in the supernatants was calculated from

$$
\frac{\text { Experimental release }- \text { Spontaneous release }}{\text { Maximal release }- \text { Spontaneous release }} \times 100 .
$$

Abbreviations used: Act D, actinomycin D; FCS, fetal calf serum; LPS, lipopolysaccharide; SRBC, sheep red blood cells.

Received December 13, 1988; accepted February 16, 1989.

Reprint requests: H.W. Löms Ziegler-Heitbrock, Institute for Immunology, University of Munich, Goethestr. 31, 8000 Munich, F.R.G. 
Neutralization experiments were done with $195 / 8$ monoclonal antibody (kindly provided by Dr. A. Möller) against TNF in saturating amounts as described [18].

\section{Northern Blot Analysis}

RNA was prepared according to standard protocols [3]. In brief, $20-30 \times 10^{6}$ cells were lysed with $4 \mathrm{M}$ guanidine-isothiocyanate (Fluka), $0.5 \%$ laurylsarcosine (Sigma), $25 \mathrm{mM}$ sodium citrate, and $0.1 \mathrm{M} \beta$-mercaptoethanol (Merck, Darmstadt, F.R.G.) and subjected to $\mathrm{CsCl}$ (BRL, Bethesda) density gradient centrifugation. The RNA was dissolved in $\mathrm{H}_{2} \mathrm{O}$, extracted once with phenol/chloroform/isoamylalcohol (Merck) and $20 \mu \mathrm{g} /$ slot was applied to a $1 \%$ agarose gel containing $17.8 \%$ formaldehyde (Merck). After electrophoresis RNA was blotted overnight on a nylon membrane (Amersham, Braunschweig, F.R.G.) and hybridized overnight at $65^{\circ} \mathrm{C}$ in $3 \times$ SSC, $10 \times$ Denhardt's solution, $0.1 \%$ sodium pyrophosphate (Merck), $10 \%$ dextrane sulfate (Serva, Heidelberg, F.R.G.), and $100 \mu \mathrm{g} / \mathrm{ml}$ salmon sperm (Sigma). Hybridization for TNF was done with a $0.6 \mathrm{~kb} \mathrm{Xhol} / \mathrm{HindIII}$ fragment derived from exon 4 of the human TNF gene according to Nedwin et al. [9]. This probe was labeled by random priming [4] with $\alpha 32 \mathrm{P}$ dATP (Amersham). Finally, blots were washed to $0.3 \times$ SSC/0.1\%SDS at $65^{\circ} \mathrm{C}$ for $30 \mathrm{~min}$ and autoradiographed overnight with one intensifying screen. Control hybridizations were done after washing the blots in $0.1 \%$ SDS (Sigma) at $75^{\circ} \mathrm{C}$ for 30 min with a $1.7 \mathrm{~kb}$ Pst 1 fragment derived from the human actin gene [14].

\section{Phagocytosis}

Sheep red blood cells (SRBCs) (Behring, Marburg, F.R.G.) were diluted to $1 \times 10^{9} \mathrm{cells} / \mathrm{ml}$, stained for endogenous peroxidase with $60 \mu \mathrm{g} / \mathrm{ml}$ carbazole (Sigma) and $1.5 \times 10^{-2} \% \mathrm{H}_{2} \mathrm{O}_{2}$ (Merck) for $15 \mathrm{~min}$ at room temperature, washed twice with warm PBS, incubated 15 min at $37^{\circ} \mathrm{C}$ with rabbit- $\alpha$ SRBC antiserum 1:100 (Amboceptor, Behring), and finally washed another two times. Mono-Mac- 6 cells, which had been precultured with or without LPS at $10 \mathrm{ng} / \mathrm{ml}$ for $3 \mathrm{~d}$ were diluted to $1 \times 10^{6} \mathrm{cells} / \mathrm{ml}$, and $1 \times 10^{8} \mathrm{SRBC}$ were added. Cells were incubated at $37^{\circ} \mathrm{C}$ for $4 \mathrm{~h}$; nonphagocytosed SRBCs were lysed with ammonium chloride buffer; and cytospin preparations with $5 \times 10^{5}$ Mono-Mac- 6 cells were prepared. After staining according to Pappenheim the number of cells with one or more phagocytosed SRBC, was determined. For evaluation of bacterial phagocytosis $1 \times 10^{6}$ Mono-Mac-6 cells were incubated with $1 \times 10^{8}$ Staphylococcus aureus (Pansorbin, Calbiochem, La Jolla, CA) in $1 \mathrm{ml}$ of culture medium containing $2 \%$ human serum for $1 \mathrm{~h}$ at $37^{\circ} \mathrm{C}$, and cells containing one or more intracellular bacteria were enumerated in Pappenheim stains.

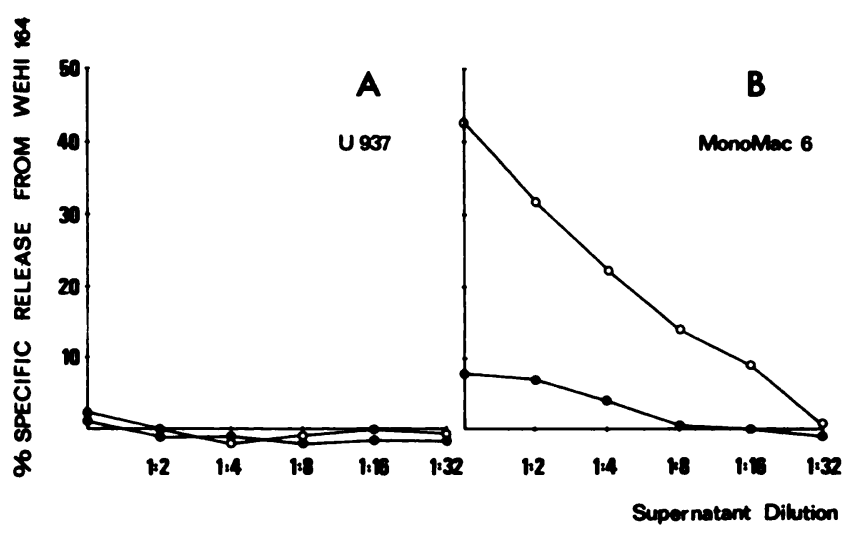

Fig. 1. TNF production in the human Mono-Mac-6 cell line is suppressed by preculture with low amounts of LPS. Cell lines were precultured for $3 \mathrm{~d}$ with or without $10 \mathrm{ng} / \mathrm{ml}$ LPS followed by washing and triggering with $1 \mu \mathrm{g} / \mathrm{ml}$ LPS for $3 \mathrm{~h}$, and TNF activity was assayed in the WEHI 164/Act D assay. Open symbols without, closed symbols with, LPS in preculture.

\section{RESULTS}

When Mono-Mac- 6 cells are cultured for $3 \mathrm{~d}$ without exogenous LPS a subsequent trigger with $1 \mu \mathrm{g} / \mathrm{ml}$ LPS results in rapid secretion of TNF into the supernatant (Fig. 1B). Dose-response studies show that LPS amounts of $100 \mathrm{pg} / \mathrm{ml}$ to $1 \mathrm{ng} / \mathrm{ml}$ are already able to induce TNF expression. Neutralization experiments with a TNF-specific antibody demonstrate a complete ablation of cytotoxicity (control antibody $51.5 \%$; anti-TNF monoclonal antibody $4 \%$ ). These experiments demonstrate that the WEHI 164/Act D assay specifically detects TNF activity in Mono-Mac-6 supernatants. Similar triggering of U937 with LPS did not result in any detectable TNF secretion (Fig. 1A).

When low amounts of LPS were present during the 3 d preculture period the TNF response in Mono-Mac-6 cells was almost completely suppressed (Fig. 1, Table 1). Hence, we asked at which level of gene expression this downregulation occurs. For this purpose total RNA was isolated from these cells preincubated with or without $100 \mathrm{ng} / \mathrm{ml}$ of LPS and triggered with $1 \mu \mathrm{g} / \mathrm{ml}$ LPS for $3 \mathrm{~h}$. Hybridization of the RNA blot with a TNF-specific probe demonstrated that LPS preincubation resulted in a strongly decreased expression of specific mRNA (Fig. 2), while for U937 there was no TNF mRNA detectable under any circumstances.

These data indicate that the LPS-induced downregulation of TNF expression apparently operates at the pretranslational level. In order to exclude that other monocyte-specific functions are impaired by such treatment we investigated phagocytic activity. As is evident from Table 2, the same preincubation with LPS results in in- 
TABLE 1. Effect of Preincubation With Low Amounts of LPS on LPS-Triggered TNF Production*

\begin{tabular}{lrrrrr}
\hline & \multicolumn{3}{c}{ U 937 } & & \multicolumn{2}{c}{ Mono-Mac-6 } \\
\cline { 2 - 3 } \cline { 5 - 6 } Exp & \multicolumn{1}{c}{} & + & & - & + \\
\hline 1 & -0.5 & -1.0 & 42.6 & 7.6 \\
2 & 2.3 & 3.3 & 50.1 & 8.5 \\
3 & -0.5 & -0.2 & 39.5 & 10.0 \\
\hline
\end{tabular}

Cells were preincubated for $3 \mathrm{~d}$ without $(-)$ or with $(+) 10 \mathrm{ng}$ LPS/ml followed by washing and triggering with $1 \mu \mathrm{g} \mathrm{LPS} / \mathrm{ml}$ for 4-6 h. TNF activity in supernatants is expressed as \% specific release from WEHI 164/Act D target cells.

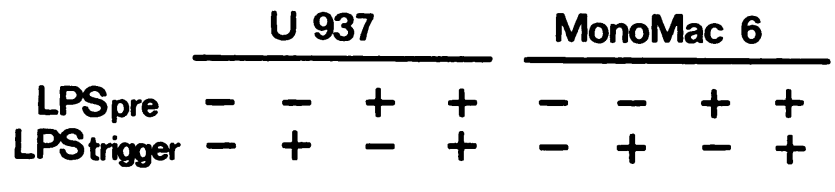

TNF

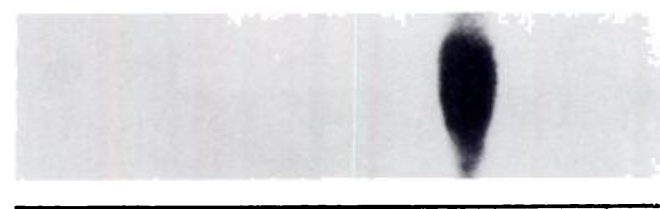

Actin

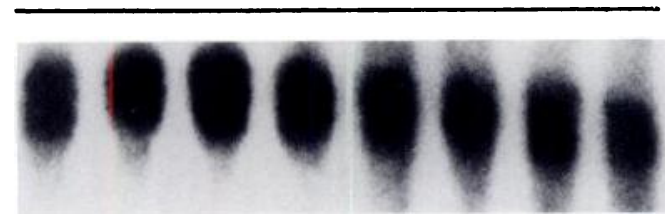

Fig. 2. TNF mRNA expression in the human Mono-Mac-6 cell line is suppressed by preculture with low amounts of LPS. Cell Iines were precultured for $3 \mathrm{~d}$ with or without $10 \mathrm{ng} / \mathrm{ml}$ LPS (LPS pro) followed by washing and triggering with $1 \mu \mathrm{g} / \mathrm{ml}$ LPS (LPS trigger) for $3 \mathrm{~h}$ as indicated. RNA blots were hybridized with a $0.6 \mathrm{~kb}$ genomic TNF probe.

creased phagocytic activity for both Staphylococcus aureus and antibody-coated erythrocytes.

\section{DISCUSSION}

The Mono-Mac- 6 cell line was established from a patient with acute monoblastic leukemia, and by using early cloning and selection of slowly growing cells, we were able to isolate a line with almost all features of human blood monocytes, i.e. phagocytosis, reactive oxygen production, enzyme production, and expression of typical cell-surface markers, including the CD14 antigen as defined by the antibodies My4 and Mo2. Consistent with the mature phenotype, we can show herein that LPS can rapidly induce TNF in the Mono-Mac-6 cell line, while in the immature monoblastic cell line U937 no such response was detected. The mRNA is first detectable at $30 \mathrm{~min}$, peaks between 1 and $3 \mathrm{~h}$, and rapidly
TABLE 2. Effect of LPS Preincubation on Phagocytic Activity on Mono-Mac-6

\begin{tabular}{lcc}
\hline & \multicolumn{2}{c}{ Positive cells (\%) } \\
\cline { 2 - 3 } Particle & - LPS & + LPS $^{\mathrm{a}}$ \\
\hline Staphylococcus aureus $(\mathrm{n}=4)$ & $28.6 \pm 9.3$ & $67.2 \pm 18.9$ \\
Antibody-coated erythrocytes $(\mathrm{n}=5)$ & $21.2 \pm 8.1$ & $60.6 \pm 11.2$ \\
\hline
\end{tabular}

a'Cells were cultured for $3 \mathrm{~d}$ with LPS at $10 \mathrm{ng} / \mathrm{ml}$ and then incubated for $1 \mathrm{~h}$ with the respective particle. Results were read by light microscopy on Pappenheim-stained cytospins.

decreases at $6 \mathrm{~h}$, a feature found for many cytokines and oncogenes [11].

Efficient stimulation of the TNF production in MonoMac-6 was, however, only possible when stringent conditions were applied in order to exclude LPS [13]. In our studies we used either LPS-free plasticware or baked glassware. Medium was filtrated through a LPSretaining column, and the fetal calf serum added contained less than $100 \mathrm{pg} / \mathrm{ml}$ of LPS. As shown herein, low amounts of LPS (1-10 $\mathrm{ng} / \mathrm{ml})$ added to the culture media can effectively prevent subsequent stimulation by LPS. Such low amounts can be inadvertently introduced into culture media by glassware or by medium ingredients. It is very possible that such low amounts of LPS that remain unnoticed interfere with the analysis of monocyte function in many instances. The downregulation of the TNF response appeared to occur at the mRNA level since little or no mRNA was detected after stimulation of LPSpreincubated Mono-Mac-6 cells (Fig. 2). The molecular mechanisms leading to the reduced levels of mRNA under these conditions are currently unknown. Whether the preculture with LPS reduces receptor-ligand interaction or whether it interferes with postreceptor events is unknown at present. Furthermore, a possible contribution of autocrine activity of TNF or other cytokines to the downregulation of TNF expression needs to be evaluated. The involvement of cytokines in an autocrine mechanism which leads to a reduction of cell growth in the U937 cell line has been demonstrated [8], and MonoMac-6, in fact, exhibits a reduced proliferation when cultured in the presence of LPS (data not shown).

The refractoriness of monocytes to a secondary LPS trigger itself is a phenomenon that has long been known in the experimental animal $[1,5-7,10]$, but the molecular mechanisms underlying this process are ill defined, and valid in vitro models do not appear to exist. The present system using LPS-pretreated Mono-Mac-6 cells offers a suitable in vitro model and we are currently analyzing the mechanisms involved in this "in vitro desensitization" process. 


\section{ACKNOWLEDGMENTS}

We acknowledge the expert technical assistance of $A$. Fütterer, N. Meyer, and D. Kieper as well as the excellent secretarial work of S. Förster. This work was supported by a grant from Deutsche Forschungsgemeinschaft (SFB 217) and by Deutsche Krebshilfe.

\section{REFERENCES}

1. Beeson, P.B. Tolerance to bacterial pyrogens. I. Factors influencing its development. J. Exp. Med. 86,29, 1947.

2. Blumenstein, M., Schmidt, B., Ward, R.A., Ziegler-Heitbrock, H.W.L., and Gurland, H.J. Altered interleukin-1 production in patients underoing hemodialysis. Nephron 50,277, 1989.

3. Chirgwin, J.J., Przbula, A.E., McDonald, R.J., and Rutter, W.J. Isolation of biologically active ribonucleic acid from sources enriched in ribonuclease. Biochemistry 18,5294, 1979.

4. Feinberg, A.P., and Vogelstein, B. A technique for radiolabeling DNA restriction endonuclease fragments to high specific activity. Anal. Biochem. 132,6, 1983.

5. Freudenberg, M.A., and Galanos, C. Induction of tolerance to lipopolysaccharide (LPS)-D-galactosamine lethality by pretreatment with LPS is mediated by macrophages. Infect. Immun. $56,1352,1988$.

6. Greisman, S.E., Young, E.J., and Woodward, W.E. Mechanisms of endotoxin tolerance. Specificity of the pyrogenic refractory state during continuous intravenous infusions of endotoxin. J. Exp. Med. 124,938, 1966.

7. Kettelhut, I.C., and Goldberg, A.L. Tumor necrosis factor can induce fever in rats without activating protein breakdown in muscle or lipolysis in adipose tissue. J. Clin. Invest. 81,1384, 1988.

8. Lindemann, A., Riedel, D., Oster, W., Mertelsmann, R., and Herrmann, F. Recombinant human granulocyte-macrophage colony-stimulating factor induces secretion of autoinhibitory monokines by U937 cells. Eur. J. Immunol. 18,369, 1988.

9. Nedwin, G.E., Naylor, S.L., Sakaguchi, A.Y., Smith, D.,
Jarett-Nedwin, J., Pennica, D., Goeddel, D.V., and Gray, P.W. Human lymphotoxin and tumor necrosis factor genes: Structure, homology and chromosomal localization. Nucleic Acids Res. $13,6361,1985$.

10. O'Malley, W.E., Achinstein, B., and Shear, M.J. Action of bacterial polysaccharide on tumors. II. Damage of sarcoma 37 by serum of mice treated with serratia marcescens polysaccharide, and induced tolerance. J. Natl. Cancer. Inst. 29,1169, 1962.

11. Shaw, G., and Kamen, R. A conserved AU sequence from the 3' untranslated region of GM-CSF mRNA mediates selective mRNA degradation. Cell 46,659, 1986.

12. Sundström, C., and Nilsson, K. Establishment and characterization of a human histiocytic lymphoma cell line (U937). Int. J. Cancer 17,565, 1976.

13. Weinberg, J.B. Endotoxin contamination and in vitro monocytemacrophage function: Methods of detecting, detoxifying, and eliminating endotoxin. In Methods for Studying Mononuclear Phagocytes. I. Obtaining and Culturing Mononuclear Phagocytes. New York: Academic Press, p. 139, 1981.

14. Weiß, E.H., Cheah, K.S.E., Grosveld, F.G., Dahl, H.H.M., Solomon, E., and Flavell, R.A. Isolation and characterization of a human collagen $\alpha 1$ (I)-like gene from a cosmid library. Nucleic Acids Res. 10,1981, 1982.

15. Ziegler-Heitbrock, H.W.L., and Riethmüller, G. A rapid assay for cytotoxicity of unstimulated human monocytes. J. Natl. Cancer. Inst. 72,23, 1984.

16. Ziegler-Heitbrock, H.W.L., Möller, A., Linke, R.P., Haas, J.G., Rieber, E.P., and Riethmüller, G. Tumor necrosis factor as effector molecule in monocyte mediated cytotoxicity. Cancer Res. 46,5947, 1986.

17. Ziegler-Heitbrock, H.W.L., Thiel, E., Fütterer, A., Herzog, V., Wirtz, A., and Riethmüller, G. Establishment of a human cell line (Mono Mac 6) with characteristics of mature monocytes. Int. J. Cancer 41,456, 1988.

18. Ziegler-Heitbrock, H.W.L., Thiel, C., Haas, J.G., Möller, A., and Riethmüller, G. Tumor necrosis factor in human monocytemediated antitumor cytotoxicity. Nat. Immun. Cell Growth Regul. 7,280, 1988. 